\title{
Pollution events observed during CARIBIC flights in the upper troposphere between South China and the Philippines
}

\author{
S. C. Lai ${ }^{1}$, A. K. Baker ${ }^{1}$, T. J. Schuck ${ }^{1}$, P. van Velthoven ${ }^{2}$, D. E. Oram ${ }^{3}$, A. Zahn ${ }^{4}$, M. Hermann ${ }^{5}$, A. Weigelt ${ }^{5}$, \\ F. Slemr ${ }^{1}$, C. A. M. Brenninkmeijer ${ }^{1}$, and H. Ziereis ${ }^{6}$ \\ ${ }^{1}$ Max Planck Institute for Chemistry, Air Chemistry Division, J.-J.-Becherweg 27, 55128, Mainz, Germany \\ ${ }^{2}$ Royal Netherlands Meteorological Institute (KNMI), P.O. Box 201, 3730 AE, de Bilt, The Netherlands \\ ${ }^{3}$ National Centre for Atmospheric Science, School of Environmental Sciences, University of East Anglia, Norwich, \\ NR4 7TJ, UK \\ ${ }^{4}$ Institut für Meteorologie und Klimaforschung (IMK), Forschungszentrum Karlsruhe, Weberstr. 5, \\ 76133 Karlsruhe, Germany \\ ${ }^{5}$ Leibniz-Institut für Troposphärenforschung (IFT), Permoserstr. 15, 04318 Leipzig, Germany \\ ${ }^{6}$ Deutsches Zentrum für Luft- und Raumfahrt (DLR), Institut für Physik der Atmosphäre, 82230 Wessling, Germany
}

Received: 19 August 2009 - Published in Atmos. Chem. Phys. Discuss.: 19 October 2009

Revised: 28 January 2010 - Accepted: 5 February 2010 - Published: 15 February 2010

\begin{abstract}
A strong pollution episode in the upper troposphere between South China and the Philippines was observed during CARIBIC flights in April 2007. Five pollution events were observed, where enhancements in aerosol and trace gas concentrations including $\mathrm{CO}, \mathrm{CO}_{2}, \mathrm{CH}_{4}$, nonmethane hydrocarbons (NMHCs) and halocarbons were observed along the flight tracks during four sequential flights. The importance of the contribution of biomass/biofuel burning was investigated using chemical tracers, emission factor analysis, back-trajectory analysis and satellite images. The Indochinese peninsula was identified as the probable source region of biomass/biofuel burning. However, enhancements in the urban/industrial tracer $\mathrm{C}_{2} \mathrm{Cl}_{4}$ during the events also indicate a substantial contribution from urban anthropogenic emissions. An estimation of the contribution of fossil fuel versus biomass/biofuel to the $\mathrm{CO}$ enhancement was made, indicating a biomass/biofuel burning contribution of $\sim 54$ to $\sim 92 \%$ of the observed $\mathrm{CO}$ enhancements. Biomass/biofuel burning was found to be the most important source category during the sampling period.
\end{abstract}

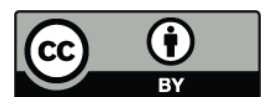

Correspondence to: S. C. Lai (senchao.lai@mpic.de)

\section{Introduction}

Over the last few decades, several major research programs have focused on Asian continental outflow, including studies of the regions discussed here. Various pollutants including aerosols, greenhouse gases, non-methane hydrocarbons (NMHCs) and halocarbons have been studied (Blake et al., 1997; Blake et al., 2003; Oshima et al., 2004). Satellite observations are also contributing to investigations in the region (Heald et al., 2004; Singh et al., 2006). However, considering the rapid changes, the vast area concerned, and the fast atmospheric chemistry in the tropics, as well as complex transport processes due to convection, additional observations are highly valuable.

The research project CARIBIC (Civil Aircraft for the Regular Investigation of the atmosphere Based on an Instrumented Container, phase II) is designed to conduct regular and long-term detailed observations of the free troposphere and upper troposphere (UT)/lower stratosphere (LS) region where passenger aircraft happen to cruise. Use is made of a fully-automated measurement container (1.5 tons) onboard an Airbus 340-600 of Lufthansa Airlines during regular passenger flights, to conduct real time trace gas and aerosol measurements and to collect aerosol and air samples on a near monthly basis (Brenninkmeijer et al., 2007) (see also www.caribic-atmospheric.com). Most information is obtained at cruising altitude $(9-11 \mathrm{~km})$, while during descent

Published by Copernicus Publications on behalf of the European Geosciences Union. 


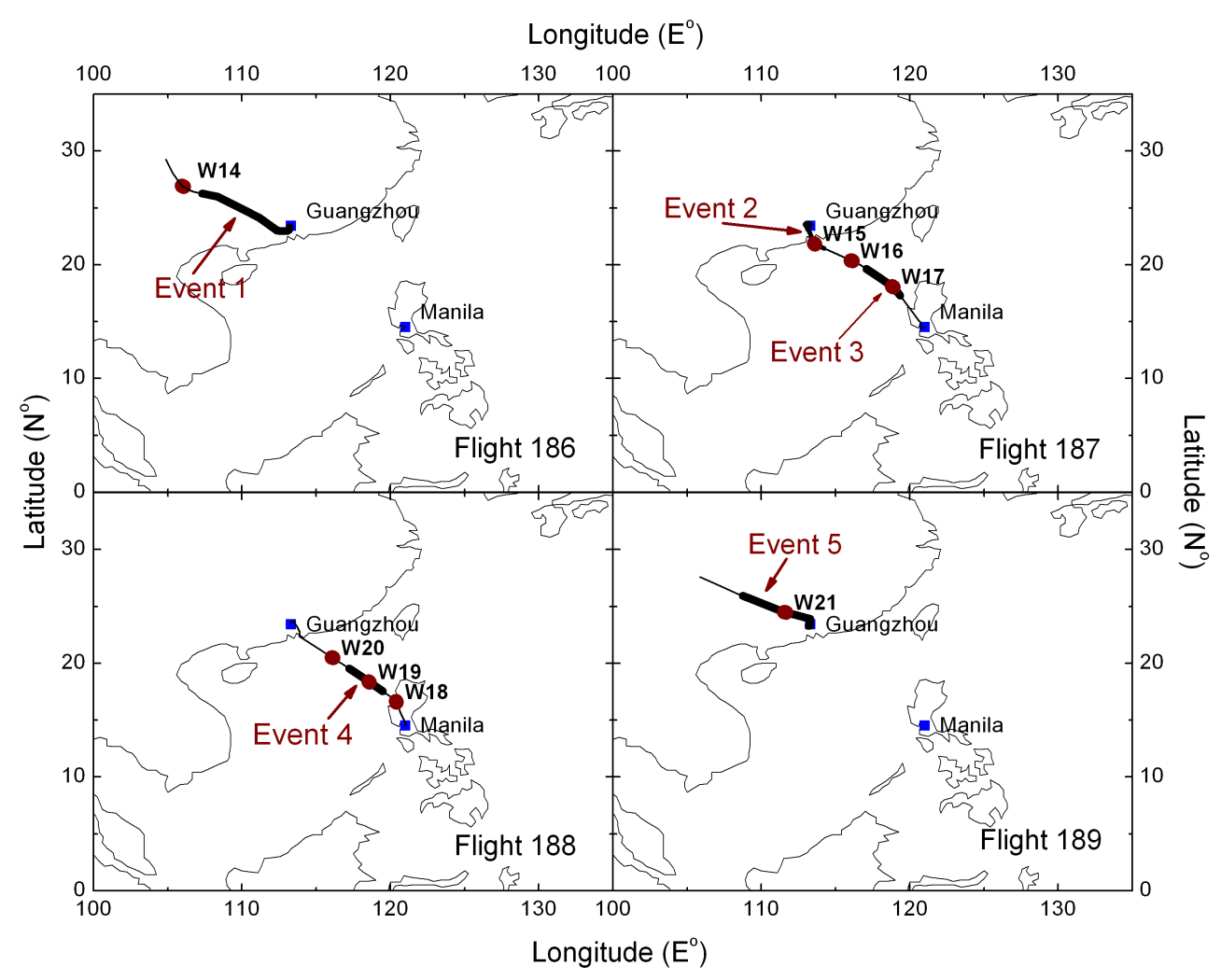

Fig. 1. Flight tracks of selected CARIBIC flights (Flight 186-189) over South China and the Philippines. Pollution events along the flight tracks are highlighted with bold lines; Dark red spots denote the whole air samples.

and ascent a limited number of measurements are made, as below flight altitudes of $\sim 500 \mathrm{hPa}$ the air intake is switched off to prevent contamination of the inlet system, tubing and equipments. Statistical analyses have shown that depending on the season and latitude, the CARIBIC aircraft intercepts a variety of airmasses, classified as from boundary layer, free troposphere, tropopause, and lower-most stratosphere (Köppe et al., 2009). Therefore, the data give information about air masses from different atmospheric domains.

Since its start in December 2004, CARIBIC (phase II) has covered several major intercontinental routes. A series of Asian flights (Frankfurt-Guangzhou-Manila) began in May 2005 and ended in March 2008. The sections of flights over South China to the Philippines cover populated and strongly industrialized regions. Based on earlier studies (Woo et al., 2003; Kondo et al., 2004; Warneke and de Gouw, 2001; Dacey and Zemmelink, 2009), it is expected that in addition to anthropogenic emissions, oceanic and biomass burning emissions also influence atmospheric composition in this region. During these flights, many events have been observed in the vicinity of Guangzhou and during the flights Guangzhou - Manila involving enhanced CO concentrations, but only a fraction of them is well characterized by coincidental whole air sample collection. The most complete data base for pollution event characterization is pro- vided by the CARIBIC flights 186-189 during April 2007 (cf. www.caribic-atmospheric.com). In this paper, these four flights have been singled out and the pollution events intersected along the flight tracks are studied. Using the chemical composition, back-trajectory analysis, cloud contact analysis and satellite images, the source region, transport pathway and the contribution of different source categories (i.e. biomass burning, biofuel burning and fossil fuel burning) are investigated here.

\section{Experimental}

The measurements took place from 06:00 to 21:00 UTC on 19 April 2007 during four flights: Frankfurt to Guangzhou, Guangzhou to Manila, and the return flights (Fig. 1). The flight sections of interest were the sections of the long-range flights 186 and 189 (Frankfurt-Guangzhou-Frankfurt) over South China, and the entire regional flights 187 and 188 (Guangzhou-Manila-Guangzhou).

In situ measurements of carbon monoxide (CO; VUV fluorescence, resolution $1 \mathrm{~s})$, ozone $\left(\mathrm{O}_{3}\right.$; UV absorption, resolution $4 \mathrm{~s})$, total reactive nitrogen $\left(\mathrm{NO}_{\mathrm{y}}\right.$; chemiluminescence, resolution $1 \mathrm{~s}$ ), sub-micrometer aerosols (Condensation Particle Counters, $>4 \mathrm{~nm}\left(\mathrm{~N}_{4}\right)$ and $>12 \mathrm{~nm}\left(\mathrm{~N}_{12}\right)$ diameter, resolution $2 \mathrm{~s})$, acetonitrile $\left(\mathrm{CH}_{3} \mathrm{CN}\right)$ and acetone 
Table 1. Concentrations of atmospheric species measured during CARIBIC flights 186-189 over South China to the Philippines and from major campaigns.

\begin{tabular}{|c|c|c|c|c|c|c|c|c|c|c|c|c|}
\hline Sample & W14 & W15 & W16 & W17 & W18 & W19 & W20 & W21 & Event & Non-event & PEM-West B & TRACE-P \\
\hline $\mathrm{CO}_{2}$ & 383.6 & 387.4 & 386.0 & 387.3 & 383.9 & 387.6 & 385.1 & 387.1 & $387.4 \pm 0.2$ & $384.5 \pm 1.1$ & N.A. & $371 \pm 1$ \\
\hline $\mathrm{CO}$ & 69.3 & 175.1 & 109.0 & 147.7 & 72.8 & 129.2 & 99.0 & 139.1 & $143.4 \pm 19.7$ & $85.9 \pm 19.5$ & $85(59-181)$ & $88 \pm 27$ \\
\hline $\mathrm{CH}_{3} \mathrm{Cl}$ & 613.9 & 701.4 & 644.4 & 709.1 & 629.8 & 713.6 & N.A. & 660.7 & $705.3 \pm 24.2$ & $629.8 \pm 15.3$ & $552(471-616)$ & $561 \pm 32$ \\
\hline $\mathrm{C}_{2} \mathrm{H}_{6}$ & 485.1 & 1219.5 & 681.1 & 787.7 & 351.8 & 715.1 & 557.5 & 937.6 & $862.7 \pm 223.2$ & $521.3 \pm 137.7$ & $538(246-1290)$ & $514 \pm 194$ \\
\hline $\mathrm{C}_{3} \mathrm{H}_{8}$ & 26.1 & 146.1 & 63.5 & 89.8 & 15.8 & 103.4 & 46.2 & 100.2 & $101.8 \pm 24.8$ & $36.2 \pm 21.2$ & $43(14-212)$ & $33 \pm 49$ \\
\hline $\mathrm{i}-\mathrm{C}_{4} \mathrm{H}_{10}$ & 2.1 & 20.3 & 7.7 & 10.5 & 1.9 & 16.7 & 4.2 & 11.3 & $14.0 \pm 4.6$ & $3.2 \pm 2.7$ & N.A. & $7 \pm 10$ \\
\hline$n-C_{4} H_{10}$ & 4.0 & 26.4 & 12.9 & 18.3 & 3.4 & 24.6 & 7.8 & 16.9 & $21.5 \pm 4.7$ & $5.9 \pm 4.4$ & N.A. & $8 \pm 8$ \\
\hline $\mathrm{O}_{3}$ & N.A. & 63.5 & 84.8 & 67.1 & 23.1 & 73.1 & 77.5 & N.A. & $67.1 \pm 4.8$ & $77.5 \pm 33.7$ & N.A. & $32 \pm 17$ \\
\hline $\mathrm{CH}_{3} \mathrm{Br}$ & 7.7 & 10.6 & 8.5 & 9.7 & 7.6 & 9.3 & N.A. & 8.6 & $9.5 \pm 0.8$ & $7.7 \pm 0.5$ & 8.6 & $8 \pm 0$ \\
\hline $\mathrm{CH}_{3} \mathrm{I}$ & N.A. & 0.5 & 0.2 & 0.4 & 0.1 & 0.3 & N.A. & 0.2 & $0.4 \pm 0.1$ & $0.1 \pm 0.1$ & $0.09(0.02-0.54)$ & N.A. \\
\hline $\mathrm{CH}_{4}$ & 1771.6 & 1799.5 & 1791.6 & 1800.8 & 1768.9 & 1803.7 & 1782.0 & 1819.6 & $1802.3 \pm 9.3$ & $1776.8 \pm 10.4$ & N.A. & $1755 \pm 13$ \\
\hline $\mathrm{C}_{2} \mathrm{Cl}_{4}$ & 0.9 & 2.2 & 1.5 & 1.6 & 1.2 & 1.9 & N.A. & 1.8 & $1.9 \pm 0.3$ & $1.2 \pm 0.3$ & 4.6 & $2 \pm 1$ \\
\hline Remark & \multicolumn{10}{|c|}{ This study, 19 April $2007,8-11.5 \mathrm{~km}$} & $\begin{array}{l}02-03,1994 \\
7-12.6 \mathrm{~km}\end{array}$ & $\begin{array}{l}02-04,2001, \\
>7 \mathrm{~km}\end{array}$ \\
\hline
\end{tabular}

* Event sample are W15, W17, W19 and W21; Non-event samples are W14, W16, W18 and W20.

** Unit for $\mathrm{CO}_{2}$ is ppm; Units for $\mathrm{CO}, \mathrm{O}_{3}$ and $\mathrm{CH}_{4}$ are ppb and ppt for other species.

*** Median values are shown for Event, Non-event statistics and those from the PEM-West B and TRACE-P.

**** Selected species during the PEM-West B and the TRACE-P please refer to Blake et al., 1997 and Russo et al., 2003.

$\left(\mathrm{CH}_{3} \mathrm{COCH}_{3}\right)$ (Proton Transfer Reaction Mass Spectrometry (PTRMS), resolution 1min) are available (Brenninkmeijer et al., 2007). Due to malfunction of the PTRMS, acetonitrile and acetone data are available only for the long range flights 186 and 189. Whole air samples were collected in glass cylinders over time periods of close to one minute. Eight such samples were collected over the region under investigation: W14 from Flight 186; W15-17 from Flight 187; W1820 from Flight 188 and W21 from Flight 189 (Fig. 1). They were analyzed in different laboratories for greenhouse gases, NMHCs, halocarbons and isotopes. Greenhouse gases $\left(\mathrm{CO}_{2}\right.$, $\mathrm{CH}_{4}, \mathrm{~N}_{2} \mathrm{O}$ and $\mathrm{SF}_{6}$ ) were analyzed at the Max Planck Institute for Chemistry (MPIC), Germany, by gas chromatography using a flame ionization detector and electron capture detector (GC-FID-ECD) (Schuck et al., 2009). Non-methane hydrocarbons were also analyzed at MPIC using GC-FID (Baker et al., 2009). Halocarbons were analyzed by GC-MS at the University of East Anglia, United Kingdom (Krol et al., 2003; Oram et al., 2010). The stable isotopic composition of $\mathrm{CO}_{2}$, namely $\delta^{13} \mathrm{C}\left(\mathrm{CO}_{2}\right)$ and $\delta^{18} \mathrm{O}\left(\mathrm{CO}_{2}\right)$, was measured by isotope ratio mass spectrometry (IRMS) at the Institute for Reference Materials and Measurements (IRMM), Belgium (Assonov et al., 2009).

Flight information including latitude, longitude, pressure, altitude and temperature was routinely recorded from the aircraft system. Except for during ascent and descent, most of the sampling altitudes were above $10 \mathrm{~km}$. The potential vorticity (PV) values and back-trajectories were calculated using data from the European Center for MediumRange Weather Forecast (ECMWF) and the model of the Royal Netherlands Meteorological Institute (KMMI) (http: //www.knmi.nl $/ \sim$ velthove/). Of all observations, $88 \%$ were conducted in the troposphere at PV values below 1.5 PVU $\left(10^{-6} \mathrm{~K} \mathrm{~kg}^{-1} \mathrm{~m}^{2} \mathrm{~s}^{-1}\right)$. All back-trajectories along the flight route were checked for cloud contact during the previous 2 days using a FORTRAN algorithm (Weigelt et al., 2009) overlaying back-trajectories and satellite cloud images from the International Satellite Cloud Climatology Project (ISCCP, http://isccp.giss.nasa.gov/).

\section{Pollution event characterization}

The results of in situ measurements and offline analyses of whole air samples are shown in Fig. 2 and Table 1. As shown, five pollution events can be identified by distinct enhancements of trace gases and aerosols. The continuous data show that the first event (Event 1) was encountered shortly after 06:30 UTC during Flight 186 when the aircraft was over South China. During this event, a polluted airmass was intersected at an altitude of $11.4 \mathrm{~km}$ which exhibited enhancements in $\mathrm{CO}$ (from $\sim 70 \mathrm{ppb}$ to $\sim 150 \mathrm{ppb}$ ), aerosol ( $>12 \mathrm{~nm}$, $\mathrm{N}_{12}$ from $\sim 5 \times 10^{3}$ to $\sim 50 \times 10^{3}$ particles $\left./ \mathrm{cm}^{3} \mathrm{STP}\right), \mathrm{O}_{3}$ (from $\sim 70 \mathrm{ppb}$ to $\sim 90 \mathrm{ppb}$ ), $\mathrm{CH}_{3} \mathrm{CN}$ (from $\sim 100 \mathrm{ppt}$ to $\sim 200 \mathrm{ppt}$ ) and acetone (from $\sim 350 \mathrm{ppt}$ to $\sim 1800 \mathrm{ppt}$ ). The event was observed until 07:00 UTC when the aircraft started to descend. Notably, while descending, aerosol decreased rapidly whilst $\mathrm{CO}, \mathrm{O}_{3}$ and $\mathrm{CH}_{3} \mathrm{CN}$ increased further, reaching $\sim 200 \mathrm{ppb}, \sim 100 \mathrm{ppb}$ and $\sim 250 \mathrm{ppt}$, respectively. No nucleation mode aerosol $\left(4-12 \mathrm{~nm}, \mathrm{~N}_{4-12}\right)$ enhancement was observed during this event. The particle concentration $\mathrm{N}_{4-12}$ is calculated as the difference $\mathrm{N}_{12}-\mathrm{N}_{4}$ and represents the concentration of particles larger than $4 \mathrm{~nm}$ and smaller than $12 \mathrm{~nm}$, which have a very short lifetime (on the order of hours) (Hermann et al., 2003). Unfortunately no whole air sample was collected during this particular event. As the 


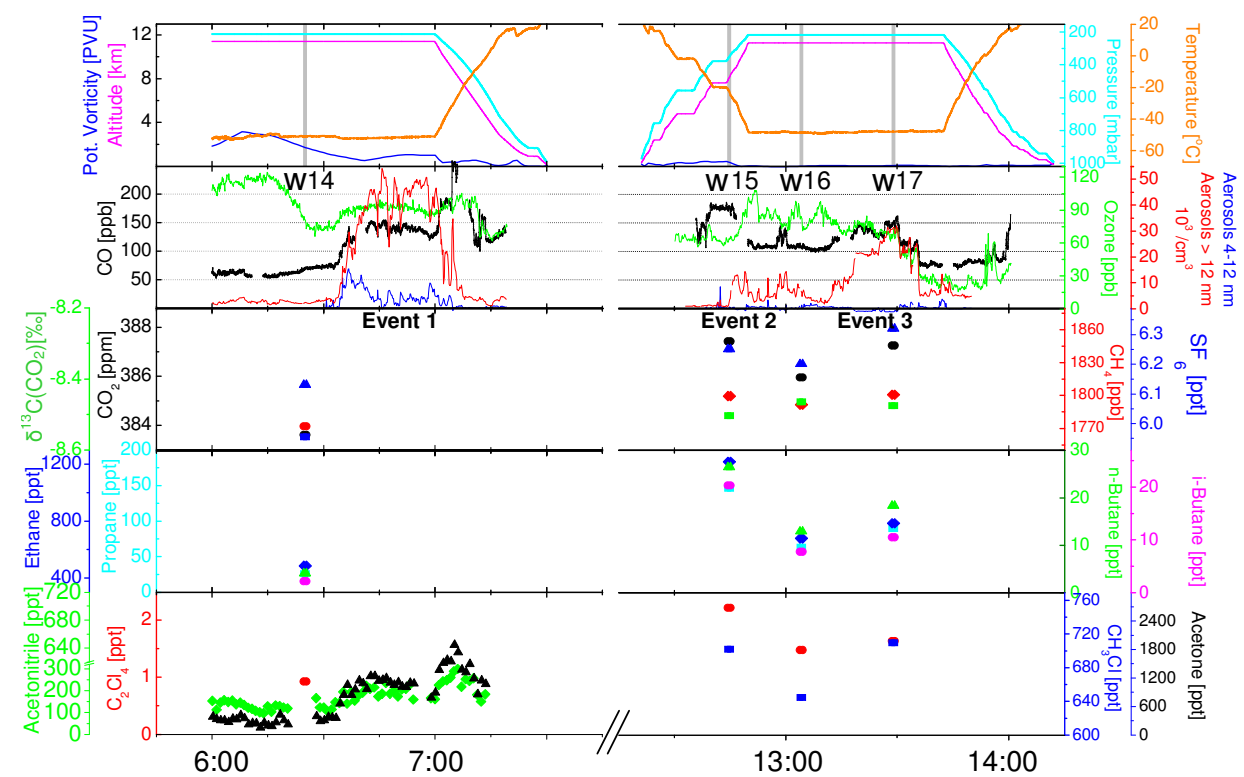

(a)

Time (UTC)

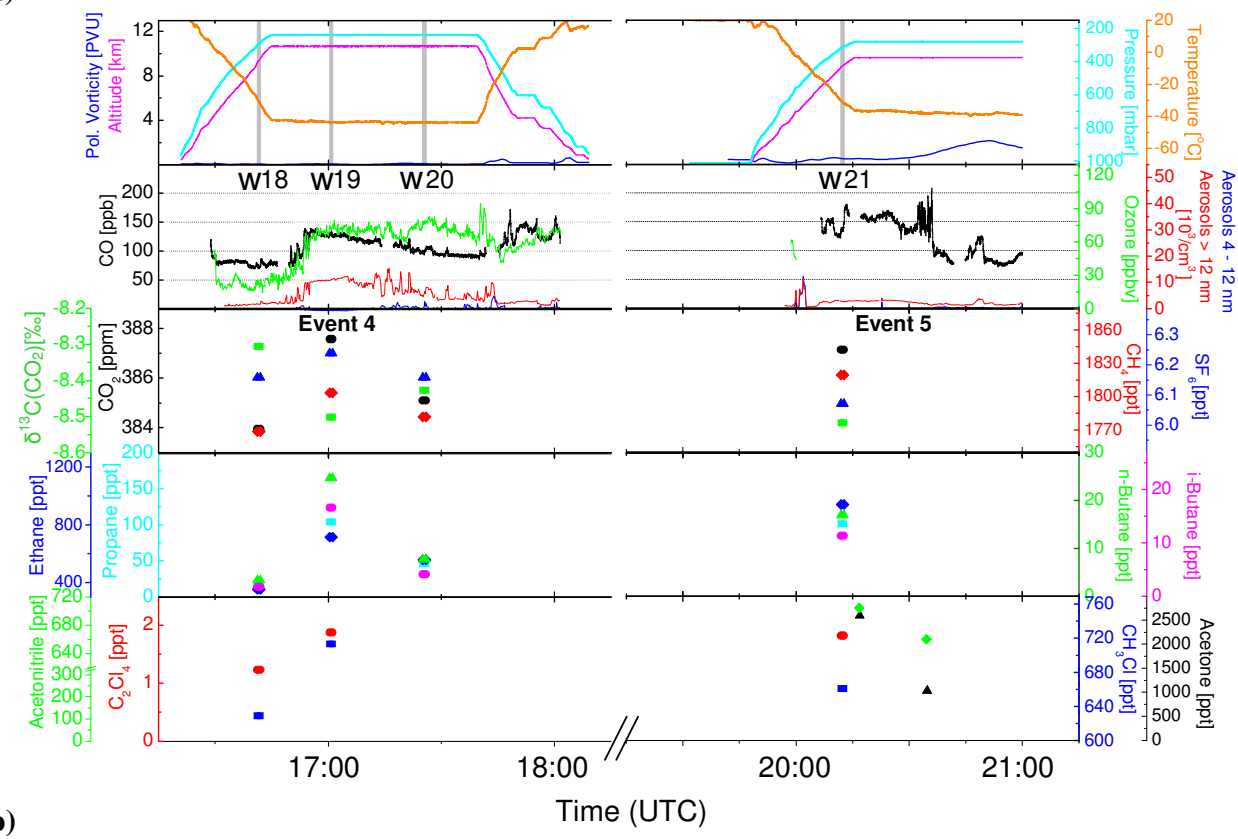

Fig. 2. Data overviews for flights 186-189: (a) for Flight 186 and 187; (b) for Flight 188 and 189. Panels from top to bottom (i) Flight parameters of altitude, potential vorticity, pressure, temperature and whole air samples (grey bars); (ii) In situ measurements of $\mathrm{CO}$, $\mathrm{O}_{3}$, $\mathrm{N}_{4-12}$ and $\mathrm{N}_{12}$; (iii) $\delta^{13} \mathrm{C}\left(\mathrm{CO}_{2}\right), \mathrm{CO}_{2}, \mathrm{CH}_{4}$ and $\mathrm{SF}_{6}$; (iv) Ethane, propane, n-butane and i-butane; (v) $\mathrm{C}_{2} \mathrm{Cl}_{4}, \mathrm{CH}_{3} \mathrm{Cl}_{1}$ acetonitrile and acetone.

CARIBIC whole air sampling is designed to obtain representative information, air samples are taken at predetermined intervals over the long distance flights. Prior to reaching this event, W14 had been collected in the tropopause region at a higher PV level ( $\sim 2$ PVU). Correspondingly lower levels of trace gases were found in Sample W14.

Atmos. Chem. Phys., 10, 1649-1660, 2010
After a $\sim 5 \mathrm{~h}$ stopover in Guangzhou, the aircraft departed for Manila (Flight 187) and it encountered another pollution event (Event 2) during ascent beginning at about 12:45 UTC at $\sim 8 \mathrm{~km}$ altitude. A strong $\mathrm{CO}$ enhancement (from $\sim 120$ to $\sim 180 \mathrm{ppb}$ ) and a brief $\mathrm{N}_{12}$ enhancement (from $\sim 1 \times 10^{3}$ to $\sim 10 \times 10^{3}$ particles $/ \mathrm{cm}^{3} \mathrm{STP}$ ) were observed. Sample W15 was collected within this event and contained the highest mixing ratios of ethane $\left(\mathrm{C}_{2} \mathrm{H}_{6}\right)$, propane 
$\left(\mathrm{C}_{3} \mathrm{H}_{8}\right)$, n-butane $\left(\mathrm{n}-\mathrm{C}_{4} \mathrm{H}_{10}\right)$, i-butane $\left(\mathrm{i}-\mathrm{C}_{4} \mathrm{H}_{10}\right)$ and perchloroethylene $\left(\mathrm{C}_{2} \mathrm{Cl}_{4}\right)$ of any sample discussed here. A non-event period with a strong decrease in trace gas levels, except for $\mathrm{O}_{3}$ which actually increased, was then observed while the aircraft climbed to a cruising altitude of $\sim 11 \mathrm{~km}$ from 12:50 UTC to 13:15 UTC. Carbon monoxide, alkanes and $\mathrm{C}_{2} \mathrm{Cl}_{4}$, which will be discussed later, were $40 \%$ or more lower during this period (Sample W16) than in sample W15. At 13:15 UTC, Event 3, with enhancements in $\mathrm{CO}, \mathrm{N}_{12}$ and $\mathrm{NO}_{\mathrm{y}}$ was encountered, with peak values of $\sim 150 \mathrm{ppb}$ for $\mathrm{CO}, \sim 30 \times 10^{3}$ particles $/ \mathrm{cm}^{3}$ STP for $\mathrm{N}_{12}$, and $\sim 1.8 \mathrm{ppb}$ for $\mathrm{NO}_{\mathrm{y}}$. Collection of sample W17 was coincident with these enhanced values and elevated concentrations of $\mathrm{CO}_{2}$, alkanes and halocarbons were measured. While the aircraft was approaching (Flight 187) and subsequently leaving (Flight 188) Manila, considerably lower levels of $\mathrm{CO}(\sim 70 \mathrm{ppb})$ and $\mathrm{O}_{3}(\sim 20 \mathrm{ppb})$ were observed at an altitude range of $4-8 \mathrm{~km}$. Sample W18 was collected after the aircraft had left Manila for Guangzhou at 16:40 UTC. The lowest mixing ratios of all species were measured in this sample and they were close to the background levels reported during previous campaigns (e.g. Blake et al., 1997). Back-trajectories show that the air parcel had passed over Papua New Guinea five days earlier and traveled along coastal regions of Indonesia and the South China Sea. Hence, clean oceanic air is assumed to have been the main contributor during this period, which will be used later as the background air reference.

Event 4 started at 16:50 UTC during which enhancements in $\mathrm{CO}(\sim 130 \mathrm{ppb}), \mathrm{N}_{12}\left(\sim 10 \times 10^{3}\right.$ particles $\left./ \mathrm{cm}^{3} \mathrm{STP}\right), \mathrm{O}_{3}$ ( $\sim 75 \mathrm{ppb})$, and $\mathrm{NO}_{\mathrm{y}}(\sim 1.2 \mathrm{ppb})$ were observed. Approximately 10 min later sample W19 was collected and the mixing ratio of ethane was similar to $\mathrm{W} 17$. In contrast, concentrations of shorter-lived species (inc. $\mathrm{C}_{3} \mathrm{H}_{8}, \mathrm{i}_{-} \mathrm{C}_{4} \mathrm{H}_{10}$, n$\mathrm{C}_{4} \mathrm{H}_{10}$ ) were higher than in Sample W19, showing the airmass to have had a more recent origin. Nevertheless, an enhancement of $\mathrm{O}_{3}$ indicates this airmass not to have been recent. Sample W20 collected afterwards had similar level of $\mathrm{O}_{3}(\sim 75 \mathrm{ppb})$ and lower levels of $\mathrm{CO}(\sim 100 \mathrm{ppb}), \mathrm{N}_{12}$ $\left(8 \times 10^{3}\right.$ particles $\left./ \mathrm{cm}^{3} \mathrm{STP}\right)$ and NMHCs. These mixing ratios were still slightly enhanced compared to background levels.

The last event (Event 5) was observed when the aircraft was returning to Frankfurt during flight 189 over South China at an altitude of about $9.6 \mathrm{~km}$. The $\mathrm{CO}$ concentration during the event was $\sim 150 \mathrm{ppb}$, a level similar to that detected during Event 1 but without concomitant enhancements in aerosol concentrations. Mixing ratios of $\mathrm{O}_{3}$ collected in the beginning of the event at 19:58-20:00 UTC whilst the aircraft was ascending were $\sim 50-60 \mathrm{ppb}$. Only two data points of both acetonitrile and acetone were obtained, at 20:16 UTC and 20:34 UTC. The concentrations of acetonitrile were $703 \mathrm{ppt}$ and $659 \mathrm{ppt}$ and the accompanying acetone concentrations were $2597 \mathrm{ppt}$ and $1033 \mathrm{ppt}$, respectively, all of which represent strong enhancements. Sample W21 was collected during this event.
To summarize, five pollution events were defined by $\mathrm{CO}$ enhancements. Enhancements in $\mathrm{O}_{3}$ and aerosols (especially $\mathrm{N}_{12}$ ) were also observed during Event 1-4. Event samples (W15, W17, W19 and W21, collected during Event 2-5) had elevated mean concentrations of all measured chemical species compared to non-event samples (W14, W16, W18 and W20). Compared to mean concentrations of chemical species measured at high altitude during two previous campaigns, PEM-West B and TRACE-P (Table 1), most of the compounds measured by CARIBIC were much higher. Greenhouse gases (i.e. $\mathrm{CO}_{2}, \mathrm{CO}, \mathrm{O}_{3}$ and $\mathrm{CH}_{4}$ ), alkanes (i.e. $\mathrm{C}_{2} \mathrm{H}_{6}, \mathrm{C}_{3} \mathrm{H}_{8}, \mathrm{i}-\mathrm{C}_{4} \mathrm{H}_{10}$ and $\mathrm{n}-\mathrm{C}_{4} \mathrm{H}_{10}$ ) and halocarbon (i.e. $\mathrm{CH}_{3} \mathrm{Cl}$ and $\mathrm{CH}_{3} \mathrm{I}$ ) were all enhanced relative to previous study mean concentrations, indicating that strong pollution episodes were observed during these CARIBIC flights. The concentrations of $\mathrm{CH}_{3} \mathrm{Br}$ and $\mathrm{C}_{2} \mathrm{Cl}_{4}$ were close to those from the previous campaigns.

\section{Discussion}

As in other studies, increased $\mathrm{CO}$ was the most evident signal for the intersected plumes (Kondo et al., 2004; Matsueda and Inoue, 1999; Russo et al., 2003). Carbon monoxide found during pollution events is mainly the product of incomplete combustion of fossil fuels, biofules and biomass in general. It is also formed as an intermediate in the oxidation of $\mathrm{CH}_{4}$, and other hydrocarbons (Logan et al., 1981). A significant correlation was found between integrals of continuous $\mathrm{CO}$ mixing ratios integrated over the sampling period and the $\mathrm{CO}_{2}$ mixing ratios measured in the individual air samples $\left(R^{2}=0.87\right)$, clearly showing that burning is a common source. When air is in contact with the surface, and photosynthesis removes $\mathrm{CO}_{2}$, a negative correlation between $\mathrm{CO}$ and $\mathrm{CO}_{2}$, or a lack of any correlation, would be expected (Potosnak et al., 1999). This has not been the case and the net $\mathrm{CO}_{2}$ uptake must have been small compared to production.

Though $\mathrm{CO}_{2}$ variability during this episode is limited to $3.6 \mathrm{ppm}$ only (from 384.0 to $387.7 \mathrm{ppm}$ ), a strong negative correlation between $\delta^{13} \mathrm{C}\left(\mathrm{CO}_{2}\right)$ (ranging from $8.53 \%$ o to $-8.25 \%$ o) and $1 / \mathrm{CO}_{2}$ is found $\left(R^{2}=0.86\right)$. This correlation is due to the combustion source, as confirmed by the positive correlation between $\mathrm{CO}$ and $\mathrm{CO}_{2}$. Fossil fuel burning and biomass/biofuel burning are possible candidates but these two cannot be resolved by using isotope data. Airmasses from the fossil fuel and/or biomass/biofuel source bring $\mathrm{CO}_{2}$ with $\delta^{13} \mathrm{C}\left(\mathrm{CO}_{2}\right)$ lower than background values. In first instance, fossil fuel and modern biomass basically correspond to the material produced by photosynthesis (photosynthesis preferentially uptakes ${ }^{12} \mathrm{C}$ and brings the air composition towards higher $\delta^{13} \mathrm{C}\left(\mathrm{CO}_{2}\right)$ and lower $\left.\mathrm{CO}_{2}\right)$. In fact, trends due to combustion and photosynthesis are of a similar slope. All in all, though $\delta^{13} \mathrm{C}\left(\mathrm{CO}_{2}\right)$ does not allow for distinction between these combustion sources (fossil fuel and biomass have low $\delta^{13} \mathrm{C}$ being variable in a certain range), the flight 
clearly illustrates that (large) combustion can be responsible for detected $\delta^{13} \mathrm{C}\left(\mathrm{CO}_{2}\right)$ shifts. Detection of $\delta^{18} \mathrm{O}\left(\mathrm{CO}_{2}\right)$ shifts related to combustion is not possible in this case.

Furthermore, the NMHCs, $\mathrm{C}_{2} \mathrm{H}_{6}, \mathrm{C}_{3} \mathrm{H}_{8}, \mathrm{n}-\mathrm{C}_{4} \mathrm{H}_{10}$ and i- $\mathrm{C}_{4} \mathrm{H}_{10}$, are found to be strongly correlated with $\mathrm{CO}$ $\left(R^{2}>0.83\right)$. They also act, together with other volatile organic compounds (VOCs), as precursors for continued $\mathrm{O}_{3}$ formation. As is mentioned, an increase in $\mathrm{O}_{3}$ was observed during the pollution events at elevated level of $\sim 60-90 \mathrm{ppb}$ compared to the background level of $\sim 30 \mathrm{ppb}$.

Enhancements in $\mathrm{N}_{12}$ were observed during Events 1-4 (Fig. 2). However, except for a small increase during Event 1 , no increase in $\mathrm{N}_{4-12}$ was observed during the other events. The large increase in $\mathrm{N}_{12}$ (sum of Aitken mode and accumulation mode particles) can be attributed to rapid air transport from lower altitudes and/or formation during plume evolution (Hermann et al., 2003). However, the absence of elevated $\mathrm{N}_{4-12}$ concentrations precludes a substantial contribution of fresh in-situ particle formation. Summarizing the slight increases in $\mathrm{O}_{3}$ and the absence (or only small increase) of ultrafine particle $\left(\mathrm{N}_{4-12}\right)$ enhancement during the five events suggest that the airmasses observed during the events were photochemically aged. Moreover, the concomitant strong acetone enhancements observed during Event 1 and, especially, during Event 5 over South China also imply secondary acetone formation during the airmass aging (Holzinger et al., 2005; Jost et al., 2003).

Asian continental outflow contains a complex mixture of fresh and processed emissions from combustion, industrial activities, and biomass burning/biofuel burning as evidenced by previous campaigns along the western Pacific coast (Blake et al., 1997, 2003; Russo et al., 2003). Fossil fuel burning was reported to be an important contributor across large areas of the Asian continent, especially in the fast developing regions of China and Southeast Asia (Russo et al., 2003; Woo et al., 2003). In East Asia, transport from South Korea and Japan is also depicted in the regional emissions (Blake et al., 2003; Carmichael et al., 2003). Biomass burning in Southeast Asia, India and Siberia has been reported as an important source for the Asian continental outflow (Russo et al., 2003; Thompson et al., 2001; Kondo et al., 2004). However, the importance of biofuel burning in the Asian countries, especially in Southeast Asia and central China, was also suggested by a previous study (Streets et al., 2003).

Back-trajectories during the selected flights show that the air mainly passed over regions to the southwest of the flight track (Fig. 3). The pertinent region in Southeast Asia is the Indochinese Peninsula. The increased emission of fossil fuel related compounds and the influence of biomass burning have previously been discussed in the monitoring of Southeast Asian outflow (Kondo et al., 2004). To obtain a clearer picture and to estimate the contributions from different source types, it is necessary to analyze carefully the variations of other species and the relationship between trace gases.

Firstly, the contribution of biomass/biofuel burning is taken into account since springtime is the dry season in Southeast Asia during which combustion is prolific and is caused by natural and/or anthropogenic processes (Christopher and Kimberly, 1996). Acetonitrile is a unique tracer of biomass burning (Andreae et al., 2001). As is mentioned above, high $\mathrm{CH}_{3} \mathrm{CN}$ concentrations were observed during Events 1 and 5 over South China. During Event 1, a significant correlation was found between $\mathrm{CO}$ and $\mathrm{CH}_{3} \mathrm{CN}$ $\left(R^{2}=0.79\right)$. The $\mathrm{CH}_{3} \mathrm{CN}$ increases and strong correlation with CO imply that the observed airmasses contain biomass burning effluents. The similar pattern of acetone increases during Event 1 and 5 can also be attributed to biomass burning and/or biofuel related sources (as a direct emission or from photochemical formation) (Singh et al., 1994; Jost et al., 2003). Although $\mathrm{CH}_{3} \mathrm{CN}$ data are unfortunately not available during flights 187 and $188, \mathrm{CH}_{3} \mathrm{Cl}$, which is another useful biomass burning tracer and was found to be correlated significantly with $\mathrm{CH}_{3} \mathrm{CN}$ in the southeastern Asian biomass burning plume (Kondo et al., 2004), correlates well with $\mathrm{CO}\left(R^{2}>0.72\right)$ in all selected samples. These findings indicate that biomass/biofuel burning was a substantial, or even predominant, contributor to the chemical composition of the observed airmasses. However, the relative contribution of biomass burning and biofuel burning still needs to be considered.

The emission factors (EFs) of $\Delta \mathrm{X} / \Delta \mathrm{CO}_{2}$ and $\Delta \mathrm{X} / \Delta \mathrm{CO}$ (Table 2) are now used to show the enhancements of species over their background levels, i.e. $\Delta \mathrm{X} / \Delta \mathrm{CO}=\left(\mathrm{X}_{\mathrm{event}}\right.$ - $\left.\mathrm{X}_{\text {background }}\right) /\left(\mathrm{CO}_{\text {event }}-\mathrm{CO}_{\text {background }}\right)$ (Andreae and Merlet, 2001). Mixing ratios from W18 were used to represent background levels because they are low and the back-trajectories show that the sampled air was not affected by recent pollution. We also note that they are close to the regional background levels reported by others (Blake et al., 1997; Russo et al., 2003).

The $\Delta \mathrm{CO} / \Delta \mathrm{CO}_{2}$ ratios of $15.6-29.3 \mathrm{ppb} / \mathrm{ppm}$ in our air samples are much lower than those cited for fresh tropical forest fire plumes (Andreae and Merlet, 2001; Mauzerall et al., 1998). Moreover they are lower than those determined for strong biomass burning events measured in a more southerly region (near Singapore) in 1997 (strong El Niño related fires) with a value of $89 \mathrm{ppb} / \mathrm{ppm}$ (Matsueda and Inoue, 1999). The contribution of biofuel burning may lower $\Delta \mathrm{CO} / \Delta \mathrm{CO}_{2}$ ratio because of its higher burning efficiency (Andreae and Merlet, 2001). Despite this, the contribution of fossil fuel burning may be a more important reason for the low $\Delta \mathrm{CO} / \Delta \mathrm{CO}_{2}$ ratio. During the TRACE-P campaign, the $\Delta \mathrm{CO} / \Delta \mathrm{CO}_{2}$ value of $13 \mathrm{ppb} / \mathrm{ppm}$ was found in Southeast Asian outflow in February-April, 2001 which is close to the ratio we observed. This value was suggested to be due not only to biomass/biofuel burning but also to fossil fuel emissions (Russo et al., 2003). Furthermore, $\Delta \mathrm{CH}_{4} / \Delta \mathrm{CO}$ 


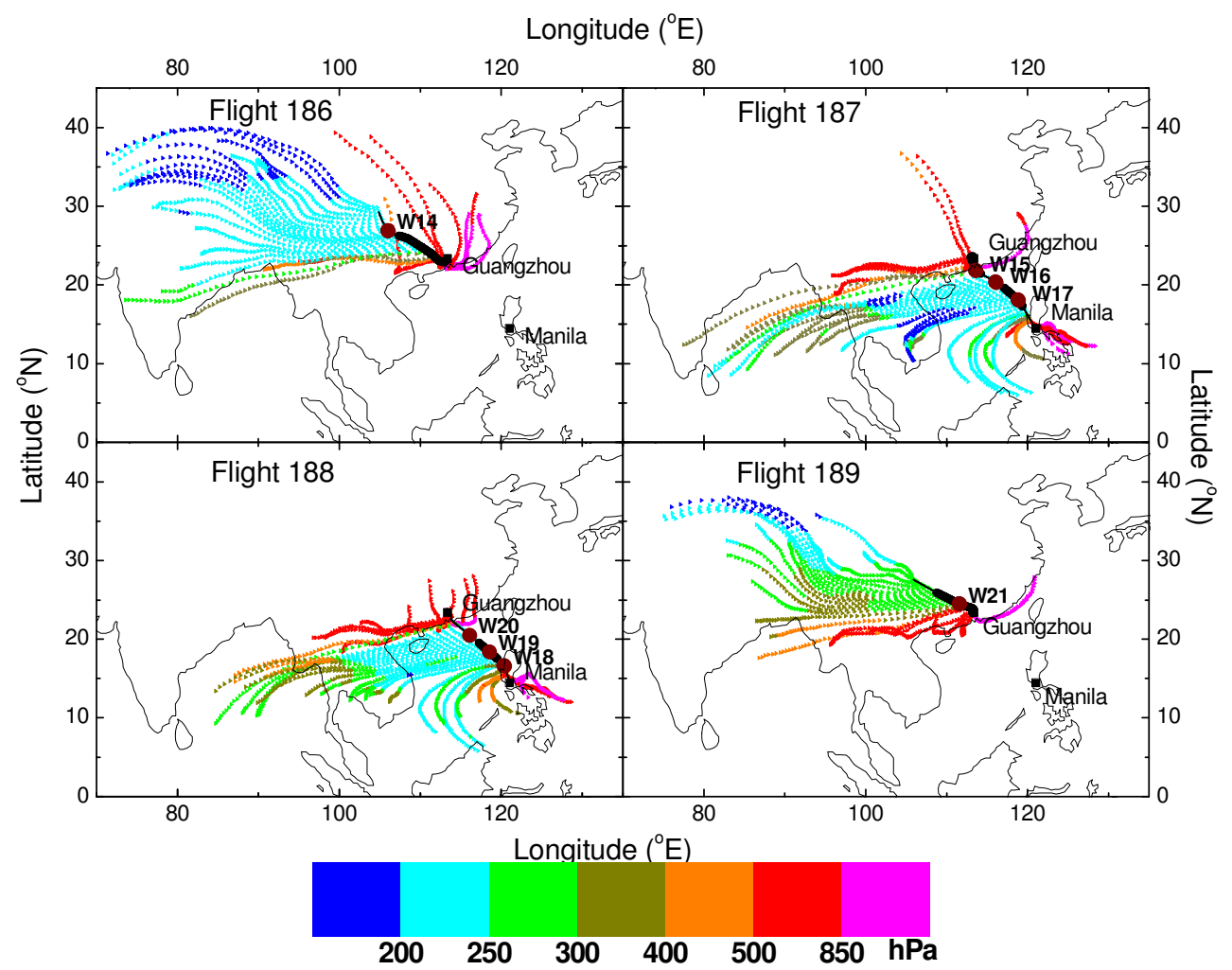

Fig. 3. 2 day back-trajectories of flights 186-189. Colour scale gives altitude in hPa. More back-trajectory information at (www.knmi.nl/ samenw/campaign_support/CARIBIC/). Pollution events along the flight tracks are highlighted with bold lines; Dark red spots denote the whole air samples.

Table 2. Emission ratios during the CARIBIC flights.

\begin{tabular}{|c|c|c|c|c|c|c|c|c|c|c|c|c|}
\hline Flight & Sample & $\begin{array}{l}\Delta \mathrm{CO} \\
/ \Delta \mathrm{CO}_{2}\end{array}$ & $\begin{array}{l}\Delta \mathrm{CH}_{3} \mathrm{Cl} \\
/ \triangle \mathrm{CO}\end{array}$ & $\begin{array}{l}\Delta \mathrm{C}_{2} \mathrm{H}_{6} \\
/ \Delta \mathrm{CO}\end{array}$ & $\begin{array}{l}\Delta \mathrm{C}_{3} \mathrm{H}_{8} \\
/ \Delta \mathrm{CO}\end{array}$ & $\begin{array}{l}\Delta i- \\
\mathrm{C}_{4} \mathrm{H}_{10} \\
/ \Delta \mathrm{CO}\end{array}$ & $\begin{array}{l}\Delta n- \\
\mathrm{C}_{4} \mathrm{H}_{10} \\
/ \Delta \mathrm{CO}\end{array}$ & $\begin{array}{l}\Delta \mathrm{O}_{3} \\
/ \triangle \mathrm{CO}\end{array}$ & $\begin{array}{l}\Delta \mathrm{CH}_{3} \mathrm{Br} \\
/ \triangle \mathrm{CO}\end{array}$ & $\begin{array}{l}\Delta \mathrm{CH}_{3} \mathrm{I} \\
/ \Delta \mathrm{CO}\end{array}$ & $\begin{array}{l}\Delta \mathrm{CH}_{4} \\
/ \Delta \mathrm{CO}\end{array}$ & $\begin{array}{l}\Delta N_{2} \mathrm{O} \\
/ \Delta \mathrm{CO}\end{array}$ \\
\hline F187 & W15 & 29.3 & 0.7 & 8.5 & 1.3 & 0.2 & 0.2 & 0.4 & 0.03 & 0.0037 & 0.3 & 0.0048 \\
\hline F187 & W16 & 17.9 & 0.4 & 9.1 & 1.3 & 0.2 & 0.3 & 1.7 & 0.02 & 0.0021 & 0.6 & 0.0154 \\
\hline F187 & W17 & 22.6 & 1.1 & 5.8 & 1.0 & 0.1 & 0.2 & 0.6 & 0.03 & 0.0040 & 0.4 & 0.0075 \\
\hline F188 & W19 & 15.6 & 1.5 & 6.4 & 1.6 & 0.3 & 0.4 & 0.9 & 0.03 & 0.0037 & 0.6 & 0.0115 \\
\hline F188 & W20 & 22.6 & N.A. & 7.9 & 1.2 & 0.1 & 0.2 & 2.1 & N.A. & N.A. & 0.5 & 0.0122 \\
\hline F189 & W21 & 20.9 & 0.5 & 8.8 & 1.3 & 0.1 & 0.2 & N.A. & 0.01 & 0.0015 & 0.8 & 0.0066 \\
\hline
\end{tabular}

* The emission factors for W14 are not provided because it was taken in the tropopause region with lower mixing ratios of trace gases;

** Unit for $\mathrm{CO}_{2}$ is ppm; Units for $\mathrm{CO}, \mathrm{O}_{3}$ and $\mathrm{CH}_{4}$ are ppb and ppt for other species.

ratios varied from $0.3-0.8$, which are higher than that for fresh biomass/biofuel burning airmasses and close to values for airmasses impacted by anthropogenic emissions (Andreae and Merlet, 2001; Mauzerall et al., 1998; Muhle et al., 2002).

$\Delta \mathrm{O}_{3} / \Delta \mathrm{CO}$ ratios were variable $(0.4-2.1)$, and are higher than the reported $\Delta \mathrm{O}_{3} / \Delta \mathrm{CO}$ ratio in fresh biomass burning plumes (Andreae and Merlet, 2001; Mauzerall et al., 1998). In event samples (i.e. $\mathrm{W} 15, \mathrm{~W} 17$ and $\mathrm{W} 19), \Delta \mathrm{O}_{3} / \Delta \mathrm{CO}$ ra- tios varied from 0.4 to 0.9 , which are higher than those reported in non-aged air (e.g. $\Delta \mathrm{O}_{3} / \Delta \mathrm{CO} \approx 0.1$ after $2 \mathrm{~h}$ ageing in an African biomass burning airmass) (Jost et al., 2003). The ratios are also higher than that of $0.22 \pm 0.001$ was obtained in the middle troposphere (MT, 4-8 km) in Southeast Asia during the TRACE-P (Kondo et al., 2004). It suggests that these airmasses were photochemically aged because the production of $\mathrm{O}_{3}$ can be triggered and increase dramatically during biomass burning influenced events (Jost et al., 2003; 
Table 3. Estimation of fossil fuel $\mathrm{CO}$ enhancement $\left(\Delta \mathrm{CO}_{F F}\right)$ versus biomass/biofuel CO enhancement $\left(\Delta \mathrm{CO}_{F F}\right) \mathrm{using}_{2} \mathrm{Cl}_{4}$ as a tracer.

\begin{tabular}{llllllllll}
\hline Flight & Sample & $\begin{array}{l}\mathrm{CO} \\
(\mathrm{ppb})\end{array}$ & $\begin{array}{l}\mathrm{C}_{2} \mathrm{Cl}_{4} \\
(\mathrm{ppt})\end{array}$ & $\begin{array}{l}\Delta \mathrm{CO} \\
(\mathrm{ppb})\end{array}$ & $\begin{array}{l}\Delta \mathrm{C}_{2} \mathrm{Cl}_{4} \\
(\mathrm{ppb})\end{array}$ & $\begin{array}{l}\Delta \mathrm{CO}_{F F} \\
(\mathrm{ppb})\end{array}$ & $\begin{array}{l}\Delta \mathrm{CO}_{B B} \\
(\mathrm{ppb})\end{array}$ & $\Delta \mathrm{CO}_{F F} / \mathrm{CO}$ & $\begin{array}{l}\Delta \mathrm{CO}_{B B} / \\
\Delta \mathrm{CO}\end{array}$ \\
\hline $\mathrm{F} 187$ & 15 & 175.1 & 2.2 & 102.3 & 1.0 & $15.4-37.2$ & $65.1-86.9$ & $15-36 \%$ & $64-85 \%$ \\
$\mathrm{~F} 187$ & 16 & 109.0 & 1.5 & 36.2 & 0.3 & $4.6-11.2$ & $25.0-31.6$ & $13-31 \%$ & $69-87 \%$ \\
$\mathrm{~F} 187$ & 17 & 147.7 & 1.6 & 74.9 & 0.4 & $6.2-14.9$ & $60.0-68.7$ & $8-20 \%$ & $80-92 \%$ \\
$\mathrm{~F} 188$ & 18 & 72.8 & 1.2 & - & - & - & - & - & - \\
$\mathrm{F} 188$ & 19 & 129.2 & 1.9 & 56.4 & 0.7 & $10.8-26.0$ & $30.4-45.6$ & $19-46 \%$ & $54-81 \%$ \\
$\mathrm{~F} 188$ & 20 & 99.0 & N.A. & 26.2 & N.A. & N.A. & N.A. & N.A. & N.A. \\
F189 & 21 & 139.1 & 1.8 & 66.3 & 0.6 & $9.2-22.3$ & $44.0-57.1$ & $14-34 \%$ & $66-86 \%$ \\
\hline
\end{tabular}

* $\Delta \mathrm{CO}$ stands for the enhancement in $\mathrm{CO}$; CO concentration in W18 was used as the background.

Thompson et al., 2001). Even higher $\Delta \mathrm{O}_{3} / \Delta \mathrm{CO}$ ratios were observed in the non-event samples (1.7 and 2.1), showing that the air collected during the non-event periods was more aged than that during the events. Nevertheless, the highly elevated $\Delta \mathrm{O}_{3} / \Delta \mathrm{CO}$ ratio obtained along the flight tracks (both during event and during non-event periods) may be due to the strong transport from biomass/biofuel burning affected regions, e.g. Southeast Asia in which about $70 \%$ of $\mathrm{O}_{3}$ produced during biomass burning was found to be transported to the western Pacific (Kondo et al., 2004). This is again confirmed by the back-trajectories along the flight tracks which passed over Southeast Asia (the occurrence of combustion in this region is discussed later) 1-2 days prior.

Conversely, the EFs of alkanes, $\mathrm{CH}_{3} \mathrm{Cl}$ and $\mathrm{N}_{2} \mathrm{O}$ were all within the range of fresh smoke of biomass burning reported by previous studies. Higher EFs were found for $\mathrm{CH}_{3} \mathrm{I}$ and $\mathrm{CH}_{3} \mathrm{Br}$ which may be a result of non-biomass-burning sources e.g. oceanic emission in the Pacific Ocean (Chan et al., 2006).

The occurrence of biomass/biofuel burning and the subsequent transport are further supported by satellite observations. According to the fire map based on the detection of the Moderate Resolution Imaging Spectroradiometer (MODIS) on NASA's Terra satellite, strong fires were observed in the Indochinese Peninsula in April 2007. In particular, many fire points were detected on 18 April 2007 (Fig. 5). The fires are with high probability related to biomass burning rather than biofuel burning. Global infrared cloud images from the Space Science and Engineering Center, University of Wisconsin-Madison (SSEC) indicate that strong convection had occurred in the same region on 18 April 2007 (Fig. 5). Cloud contact analysis confirms that probed air parcels had been in contact with the convective clouds (Fig. 4). During the Event periods, 50-100\% of the back-trajectories had contacted with clouds, which gives a clear evidence of an important pathway to uplift pollutants from ground level to the UT. All observed cloud contact during Events 2-4 and half of those during Event 1 and 5 are found to have occurred over the Indochinese Peninsula, indicating it is an important source region in this case. After convection, the air parcels were entrained in the general flow and finally monitored by the CARIBIC aircraft. Back-trajectories show that the air parcels traveled over the aforementioned region 1-2 days before sampling. This is in accordance with the evidence that the intersected airmasses were photochemically aged to some degree.

Although the contribution of biomass/biofuel burning is beyond doubt, the relative contribution compared to that from other sources is not certain. The influence of fossil fuel burning can be further investigated by using the industrial/urban tracer $\mathrm{C}_{2} \mathrm{Cl}_{4}$ which is an entirely man-made compound used as a dry cleaning agent and degreasing solvent in industrial and commercial activities (Wang et al., 1995). During previous campaigns, $\mathrm{C}_{2} \mathrm{Cl}_{4}$ was suggested as a unique urban/industrial tracer in Asian continental outflow (Blake et al., 1997; Wang et al., 1995). The level of $\mathrm{C}_{2} \mathrm{Cl}_{4}$ measured during the CARIBIC flights presented here ranged from 0.9 to $2.2 \mathrm{ppt}$, which is similar to the range observed at altitudes $>7 \mathrm{~km}$ in the spring of 2001 during TRACE-P (Russo et al., 2003). The significant correlation we find between $\mathrm{CO}$ and $\mathrm{C}_{2} \mathrm{Cl}_{4}\left(R^{2}=0.88\right)$ shows that the pollution events were not only influenced by biomass/biofuel burning but also by urban/industrial sources. Urban/industrial sources of $\mathrm{CO}$ are collocated with sources of $\mathrm{C}_{2} \mathrm{Cl}_{4}$ in the urban areas. Therefore, to further clarify the contribution of different source categories to the $\mathrm{CO}$ enhancement $(\triangle \mathrm{CO})$, $\mathrm{C}_{2} \mathrm{Cl}_{4}$ is used here as a surrogate to estimate the relative contribution of urban/anthropogenic emissions, and by proxy, fossil fuel burning emissions of $\mathrm{CO}$, versus biomass/biofuel burning. The fossil fuel $\mathrm{CO}$ enhancement $\left(\triangle \mathrm{CO}_{F F}\right)$ concentration is estimated by taking the enhancement of $\mathrm{C}_{2} \mathrm{Cl}_{4}$ $\left(\Delta \mathrm{C}_{2} \mathrm{Cl}_{4}\right)$ and multiplying by a typical urban/anthropogenic $\Delta \mathrm{CO} / \Delta \mathrm{C}_{2} \mathrm{Cl}_{4}$ value in the region. $\Delta \mathrm{CO} / \Delta \mathrm{C}_{2} \mathrm{Cl}_{4}$ values reported for the Chinese urban plumes during INTEX-B in spring 2006 were variable, ranging from 15.4-37.2 (Barletta et al., 2009). Based on this range, the biomass/biofuel $\mathrm{CO}$ enhancement $\left(\triangle \mathrm{CO}_{B B}\right)$ is estimated. $\triangle \mathrm{CO}_{B B}$ is calculated as the difference of total $\mathrm{CO}$ enhancement $\left(\Delta \mathrm{CO}_{\text {total }}\right)$ and 


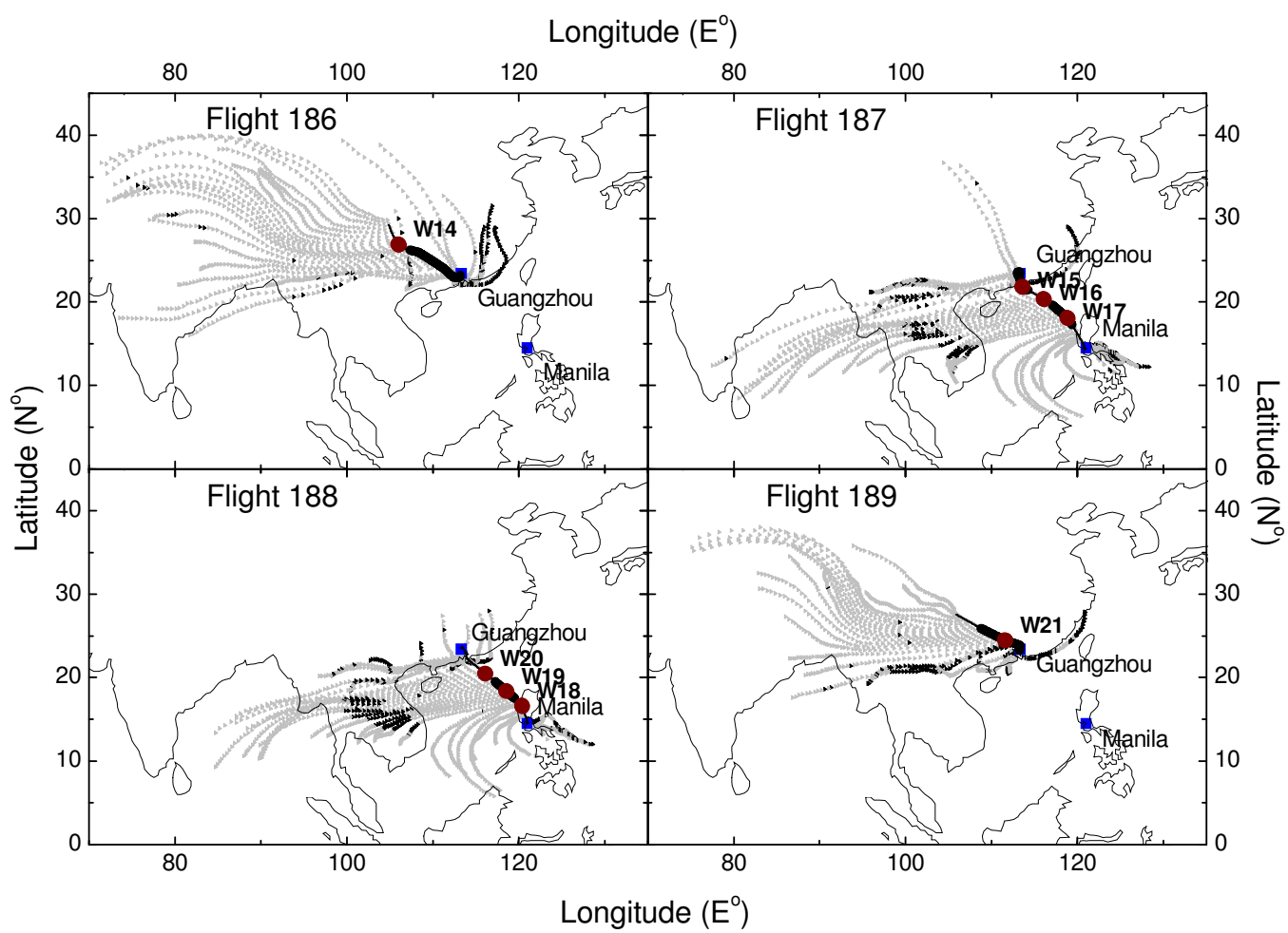

Fig. 4. Occurrence of cloud contact in the last $48 \mathrm{~h}$ of air parcels probed by CARIBIC. Black lines stand for the CARIBIC flight tracks. Back-trajectories in grey and in black denote those without and with cloud contact. During Event 1-5, 11 of 27, 8 of 10, 8 of 9, 8 of 8 and 13 of 19 back-trajectories are found to be in contact with clouds, respectively.

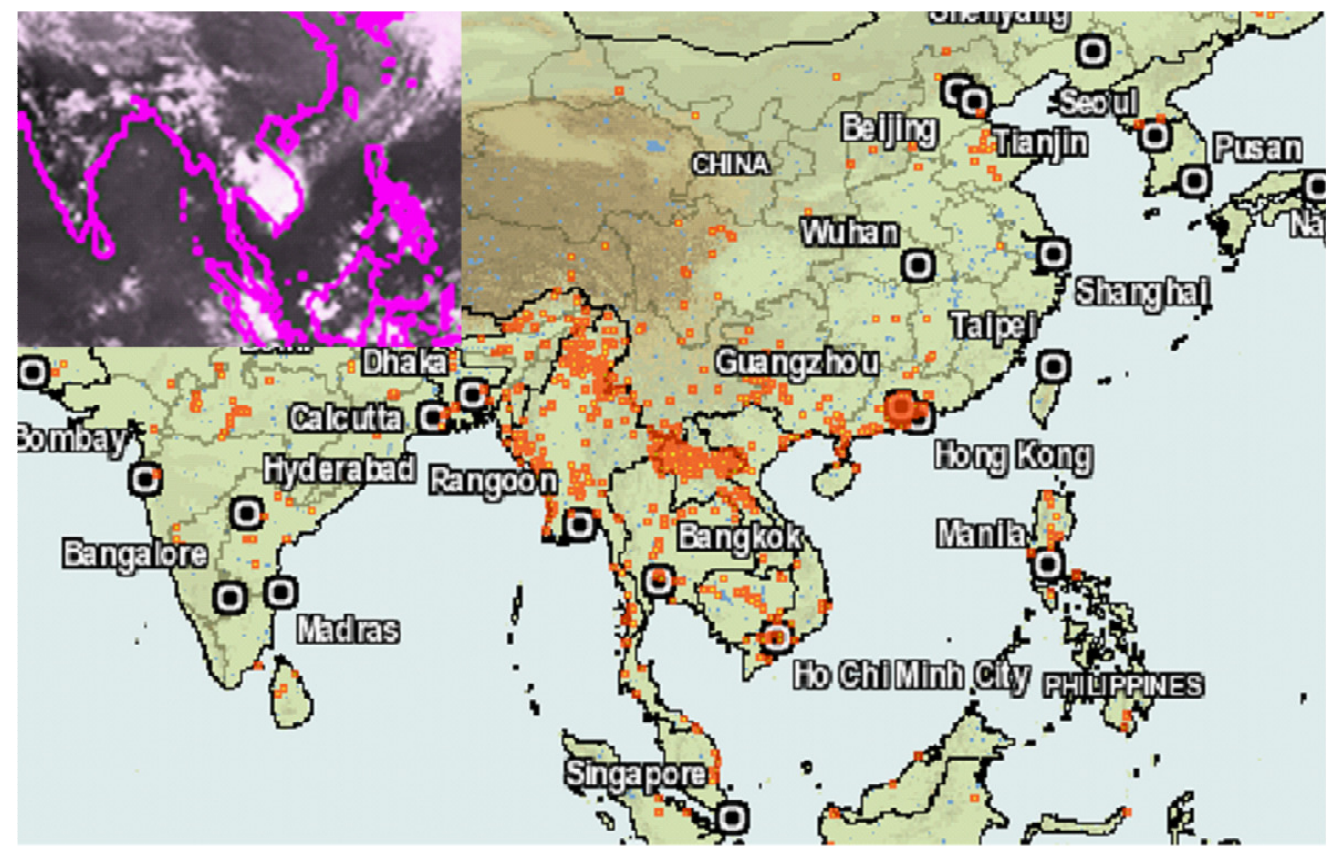

Fig. 5. Fire map and infrared cloud image on 18 April 2007. Fire map is from FIRMS web fire mapper based on the MODIS detection (http://firefly.geog.umd.edu/firemap/) showing the daily fire points; figure inserted in the upper right is the infrared cloud image from SSEC (http://www.ssec.wisc.edu/) at 12:00 UTC. 
$\Delta \mathrm{CO}_{F F}$ (Eq. 1).

$\triangle \mathrm{CO}_{B B}=\Delta \mathrm{CO}_{\text {total }}-\triangle \mathrm{CO}_{F F}$

The results show that the estimated $\triangle \mathrm{CO}_{F F}$ accounted for $8-46 \%$ of the observed $\Delta \mathrm{CO}_{\text {total }}$ (Table 3 ). In other words, the contribution of biomass/biofuel burning ranged from $\sim 54 \%$ to $\sim 92 \%$ in the observed CO enhancements. It indicates that the five observed events were highly impacted by biomass/biofuel burning. Although the estimated results do not include Event 1, the strong enhancement in the tracer $\mathrm{CH}_{3} \mathrm{CN}$ shows that biomass/biofuel burning was an important source. This gives a clue that biomass/biofuel burning in the region can cause strong pollution events in the UT and subsequently bring more pyrogenic chemicals to high altitude atmosphere. This finding is also in accordance with the previous observation that a strong contribution of biomass burning could be found during certain events from Southeast Asia (Woo et al., 2003).

However, the differentiation of contribution between biomass burning and biofuel burning is still a challenge due to that fact that both have similar chemical composition (Hao and Liu, 1994). The estimate of annual amounts of biomass burned versus biofuel burned was $175 \mathrm{Tg}$ vs. $100 \mathrm{Tg}$, i.e. $64 \%$ vs. $36 \%$, in the Indochinese Peninsula (including Laos, Myanmar, Thailand and Vietnam) (Streets et al., 2003). Annually, the period of February-April has been found as a period with strongest biomass burning (Streets et al., 2003). Considering the mentioned satellite fire map, higher contributions of biomass burning in this case would be expected. Woo et al. (2003) reported that biofuel emissions were more strongly correlated with fossil fuel emissions than biomass burning. Here the correlation between $\mathrm{CH}_{3} \mathrm{Cl}$ and $\mathrm{C}_{2} \mathrm{Cl}_{4}$ is obtained. These are regarded as the tracers of biomass/biofuel burning and urban/industrial airmasses, respectively. A good correlation between $\mathrm{CH}_{3} \mathrm{Cl}$ and $\mathrm{C}_{2} \mathrm{Cl}_{4}$ was found $\left(R^{2}=0.68\right)$, suggesting that the contribution of biofuel burning during this observed period should also be considerable. Nevertheless, without more specific information, the actual contributions of biomass versus biofuel is hard to achieve.

\section{Conclusions}

Five pollution events were observed in April 2007 during a series of CARIBIC flights over South China to Manila, Philippines. Enhancements in aerosol and a variety of trace gases such as $\mathrm{CO}, \mathrm{CO}_{2}, \mathrm{CH}_{4}$, NMHCs and halocarbons were recorded. Back-trajectories show that the airmasses probed during pollution events were mainly influenced by outflow from the Indochinese Peninsula. Signals of $\mathrm{CH}_{3} \mathrm{CN}$ during flight 186 and 189 and the significant correlation between $\mathrm{CO}$ and $\mathrm{CH}_{3} \mathrm{Cl}$ show that the pollution events were strongly impacted by biomass/biofuel burning. Fire spots in the Indochinese Peninsula indicate the occurrence of biomass burning and the satellite cloud images and back-trajectories together confirm a pathway of pollutant containing air uplifted in convection and air transport. The airmasses during pollution events were further characterized by the EFs of pyrogenic trace gases, which indicates that the events were not only affected by biomass/biofuel burning but also by anthropogenic emissions (mainly fossil fuel burning). Using $\mathrm{C}_{2} \mathrm{Cl}_{4}$ as the urban/industrial tracer, an estimation was made of the relative contribution of biomass/biomass burning and fossil fuel combustions to the observed $\mathrm{CO}$ enhancements. Biomass/biofuel burning accounted for $\sim 54$ to $\sim 92 \%$ of the observed $\mathrm{CO}$ enhancements. The five observed events are found to be substantially related to biomass/biofuel burning. However, the relative contributions of biomass and biofuel burning is still not clear.

Acknowledgements. We thank Lufthansa Airlines and Lufthansa Technik for their commitment and support. The development and operation of the CARIBIC system has been financially supported by the German Ministry of Education and Science (AFO 2000), by the European Commission's DGXII Environment RTD 4th, 5th, 6th and 7 th Framework programs, and by grants from the Max Planck Society.

The service charges for this open access publication have been covered by the Max Planck Society.

Edited by: A. Hofzumahaus

\section{References}

Andreae, M. O., Artaxo, P., Fischer, H., Freitas, S. R., Gregoire, J. M., Hansel, A., Hoor, P., Kormann, R., Krejci, R., Lange, L., Lelieveld, J., Lindinger, W., Longo, K., Peters, W., de Reus, M., Scheeren, B., Dias, M., Strom, J., van Velthoven, P. F. J., and Williams, J.: Transport of biomass burning smoke to the upper troposphere by deep convection in the equatorial region, Geophys. Res. Lett., 28, 951-954, 2001.

Andreae, M. O., and Merlet, P.: Emission of trace gases and aerosols from biomass burning, Global Biogeochem. Cy., 15, 955-966, 2001.

Assonov, S., Taylor, P., and Brenninkmeijer, C. A. M.: A system for high-quality $\mathrm{CO}_{2}$ isotope analyses of air samples collected by the CARIBIC airbus A340-600, Rapid Comm. Mass Spectrom., 23, 1347-1363, 2009.

Baker, A. K., Slemr, F., and Brenninkmeijer, C. A. M.: Analysis of non-methane hydrocarbons in air samples collected aboard the CARIBIC passenger aircraft, Atmos. Meas. Tech. Discuss., 2, 2377-2401, 2009,

http://www.atmos-meas-tech-discuss.net/2/2377/2009/.

Barletta, B., Meinardi, S., Simpson, I. J., Atlas, E. L., Beyersdorf, A. J., Baker, A. K., Blake, N. J., Yang, M., Midyett, J. R., Novak, B. J., McKeachie, R. J., Fuelberg, H. E., Sachse, G. W., Avery, M. A., Campos, T., Weinheimer, A. J., Rowland, F. S., and Blake, D. R.: Characterization of volatile organic compounds (VOCs) in Asian and north American pollution plumes during INTEX-B: identification of specific Chinese air mass tracers, Atmos. Chem. Phys., 9, 5371-5388, 2009,

http://www.atmos-chem-phys.net/9/5371/2009/. 
Blake, N. J., Blake, D. R., Chen, T. Y., Collins, J. E., Sachse, G. W., Anderson, B. E., and Rowland, F. S.: Distribution and seasonality of selected hydrocarbons and halocarbons over the western Pacific basin during PEM-West A and PEM-West B, J. Geophys. Res.-Atmos., 102, 28315-28331, 1997.

Blake, N. J., Blake, D. R., Simpson, I. J., Meinardi, S., Swanson, A. L., Lopez, J. P., Katzenstein, A. S., Barletta, B., Shirai, T., Atlas, E., Sachse, G., Avery, M., Vay, S., Fuelberg, H. E., Kiley, C. M., Kita, K., and Rowland, F. S.: NMHCs and halocarbons in Asian continental outflow during the Transport and Chemical Evolution over the Pacific (TRACE-P) Field Campaign: Comparison with PEM-West B, J. Geophys. Res.-Atmos., 108, 8806, doi:10.1029/2002jd003367, 2003.

Brenninkmeijer, C. A. M., Crutzen, P., Boumard, F., Dauer, T., Dix, B., Ebinghaus, R., Filippi, D., Fischer, H., Franke, H., Friess, U., Heintzenberg, J., Helleis, F., Hermann, M., Kock, H. H., Koeppel, C., Lelieveld, J., Leuenberger, M., Martinsson, B. G., Miemczyk, S., Moret, H. P., Nguyen, H. N., Nyfeler, P., Oram, D., O’Sullivan, D., Penkett, S., Platt, U., Pupek, M., Ramonet, M., Randa, B., Reichelt, M., Rhee, T. S., Rohwer, J., Rosenfeld, K., Scharffe, D., Schlager, H., Schumann, U., Slemr, F., Sprung, D., Stock, P., Thaler, R., Valentino, F., van Velthoven, P., Waibel, A., Wandel, A., Waschitschek, K., Wiedensohler, A., Xueref-Remy, I., Zahn, A., Zech, U., and Ziereis, H.: Civil Aircraft for the regular investigation of the atmosphere based on an instrumented container: The new CARIBIC system, Atmos. Chem. Phys., 7, 4953-4976, 2007,

http://www.atmos-chem-phys.net/7/4953/2007/.

Carmichael, G. R., Tang, Y., Kurata, G., Uno, I., Streets, D. G., Thongboonchoo, N., Woo, J. H., Guttikunda, S., White, A., Wang, T., Blake, D. R., Atlas, E., Fried, A., Potter, B., Avery, M. A., Sachse, G. W., Sandholm, S. T., Kondo, Y., Talbot, R. W., Bandy, A., Thorton, D., and Clarke, A. D.: Evaluating regional emission estimates using the TRACE-P observations, J. Geophys. Res.-Atmos., 108, 8820, doi:10.1029/2002jd003116, 2003.

Chan, C. Y., Tang, J. H., Li, Y. S., and Chan, L. Y.: Mixing ratios and sources of halocarbons in urban, semi-urban and rural sites of the Pearl River Delta, South China, Atmos. Environ., 40, 7331-7345, doi:10.1016/j.atmosenv.2006.06.041, 2006.

Christopher, D. E. and Kimberly, E. B.: Global Biomass Burning edited by: Levine, J., MIT Press, Cambridge, Mass., 663-670, 1996.

Dacey, J. W. and Zemmelink, H. J.: Dimethyl Sulfide, COS, CS2, $\mathrm{NH}_{4}$, Non-methane Hydrocarbons, Organo-halogens, in: Encyclopedia of Ocean Sciences, edited by: Steele, J. H., Elsevier Science, 131-137, 2009.

Hao, W. M. and Liu, M. H.: Spatial and Temporal Distribution of Tropical Biomass Burning, Global Biogeochem. Cy., 8, 495503, 1994

Heald, C. L., Jacob, D. J., Jones, D. B. A., Palmer, P. I., Logan, J. A., Streets, D. G., Sachse, G. W., Gille, J. C., Hoffman, R. N., and Nehrkorn, T.: Comparative inverse analysis of satellite (MOPITT) and aircraft (TRACE-P) observations to estimate Asian sources of carbon monoxide, J. Geophys. Res.-Atmos., 109, D23306, doi:10.1029/2004jd005185, 2004.

Hermann, M., Heintzenberg, J., Wiedensohler, A., Zahn, A., Heinrich, G., and Brenninkmeijer, C. A. M.: Meridional distributions of aerosol particle number concentrations in the upper tro- posphere and lower stratosphere obtained by Civil Aircraft for Regular Investigation of the Atmosphere Based on an Instrument Container (CARIBIC) flights, J. Geophys. Res.-Atmos., 108, 4114, doi:10.1029/2001jd001077, 2003.

Holzinger, R., Williams, J., Salisbury, G., Klupfel, T., de Reus, M., Traub, M., Crutzen, P. J., and Lelieveld, J.: Oxygenated compounds in aged biomass burning plumes over the Eastern Mediterranean: evidence for strong secondary production of methanol and acetone, Atmos. Chem. Phys., 5, 39-46, 2005, http://www.atmos-chem-phys.net/5/39/2005/.

Jost, C., Trentmann, J., Sprung, D., Andreae, M. O., McQuaid, J. B., and Barjat, H.: Trace gas chemistry in a young biomass burning plume over Namibia: Observations and model simulations, J. Geophys. Res.-Atmos., 108, 8482, doi:10.1029/2002jd002431, 2003.

Köppe, M., Hermann, M., Brenninkmeijer, C. A. M., heintzenberg, J., Schlager, H., Schuck, T., Slemr, F., Sprung, D., van velthoven, P. F. J., Wiedensohler, A., Zahn, A., and Ziereis, H.: Origin of aerosol particles in the mid latitude and subtropical upper troposphere and lowermost stratosphere from cluster analysis of CARIBIC data, Atmos. Chem. Phys., 9, 8413-8430, 2009, http://www.atmos-chem-phys.net/9/8413/2009/.

Kondo, Y., Morino, Y., Takegawa, N., Koike, M., Kita, K., Miyazaki, Y., Sachse, G. W., Vay, S. A., Avery, M. A., Flocke, F., Weinheimer, A. J., Eisele, F. L., Zondlo, M. A., Weber, R. J., Singh, H. B., Chen, G., Crawford, J., Blake, D. R., Fuelberg, H. E., Clarke, A. D., Talbot, R. W., Sandholm, S. T., Browell, E. V., Streets, D. G., and Liley, B.: Impacts of biomass burning in Southeast Asia on ozone and reactive nitrogen over the western Pacific in spring, J. Geophys. Res.-Atmos., 109, D15S12, doi:10.1029/2003jd004203, 2004.

Krol, M. C., Lelieveld, J., Oram, D. E., Sturrock, G. A., Penkett, S. A., Brenninkmeijer, C. A. M., Gros, V., Williams, J., and Scheeren, H. A.: Continuing emissions of methyl chloroform from Europe, Nature, 421, 131-135, doi:10.1038/Nature01311, 2003.

Logan, J. A., Prather, M. J., Wofsy, S. C., and Mcelroy, M. B.: Tropospheric Chemistry - a Global Perspective, J. Geophys. Res.Ocean. Atmos., 86, 7210-7254, 1981.

Matsueda, H. and Inoue, H. Y.: Aircraft measurements of trace gases between Japan and Singapore in October of 1993, 1996, and 1997, Geophys. Res. Lett., 26, 2413-2416, 1999.

Mauzerall, D. L., Logan, J. A., Jacob, D. J., Anderson, B. E., Blake, D. R., Bradshaw, J. D., Heikes, B., Sachse, G. W., Singh, H., and Talbot, B.: Photochemistry in biomass burning plumes and implications for tropospheric ozone over the tropical South Atlantic, J. Geophys. Res.-Atmos., 103, 19281-19282, 1998.

Muhle, J., Brenninkmeijer, C. A. M., Rhee, T. S., Slemr, F., Oram, D. E., Penkett, S. A., and Zahn, A.: Biomass burning and fossil fuel signatures in the upper troposphere observed during a CARIBIC flight from Namibia to Germany, Geophys. Res. Lett., 29, 1910, doi:10.1029/2002g1015764, 2002.

Oram, D. E., Sturrock, G. A., Penkett, S. A., and Brenninkmeijer, C. A. M.: Distribution of halocarbons in the UTLS: overview of results from CARIBIC Phase 1, Atmos. Chem. Phys. Discuss., to be submitted, 2010.

Oshima, N., Koike, M., Nakamura, H., Kondo, Y., Takegawa, N., Miyazaki, Y., Blake, D. R., Shirai, T., Kita, K., Kawakami, S., and Ogawa, T.: Asian chemical outflow to the Pacific in late 
spring observed during the PEACE-B aircraft mission, J. Geophys. Res., 109(D23), 17, 2004.

Potosnak, M. J., Wofsy, S. C., Denning, A. S., Conway, T. J., Munger, J. W., and Barnes, D. H.: Influence of biotic exchange and combustion sources on atmospheric $\mathrm{CO} 2$ concentrations in New England from observations at a forest flux tower, J. Geophys. Res.-Atmos., 104, 9561-9569, 1999.

Russo, R. S., Talbot, R. W., Dibb, J. E., Scheuer, E., Seid, G., Jordan, C. E., Fuelberg, H. E., Sachse, G. W., Avery, M. A., Vay, S. A., Blake, D. R., Blake, N. J., Atlas, E., Fried, A., Sandholm, S. T., Tan, D., Singh, H. B., Snow, J., and Heikes, B. G.: Chemical composition of Asian continental outflow over the western Pacific: Results from Transport and Chemical Evolution over the Pacific (TRACE-P), J. Geophys. Res.-Atmos., 108, 8804, doi:10.1029/2002jd003184, 2003.

Schuck, T. J., Brenninkmeijer, C. A. M., Slemr, F., Xueref-Remy, I., and Zahn, A.: Greenhouse gas analysis of air samples collected onboard the CARIBIC passenger aircraft, Atmos. Meas. Tech., 2, 449-464, 2009,

http://www.atmos-meas-tech.net/2/449/2009/.

Singh, H. B., Ohara, D., Herlth, D., Sachse, W., Blake, D. R., Bradshaw, J. D., Kanakidou, M., and Crutzen, P. J.: Acetone in the Atmosphere - Distribution, Sources, and Sinks, J. Geophys. Res.Atmos., 99, 1805-1819, 1994.

Singh, H. B., Brune, W. H., Crawford, J. H., Jacob, D. J., and Russell, P. B.: Overview of the summer 2004 intercontinental chemical transport experiment - North America (INTEX-A), J. Geophys. Res.-Atmos., 111, D24s01, doi:10.1029/2006jd007905, 2006.
Streets, D. G., Yarber, K. F., Woo, J. H., and Carmichael, G. R.: Biomass burning in Asia: Annual and seasonal estimates and atmospheric emissions, Global Biogeochem. Cy., 17, 1099, doi:10.1029/2003gb002040, 2003.

Thompson, A. M., Witte, J. C., Hudson, R. D., Guo, H., Herman, J. R., and Fujiwara, M.: Tropical tropospheric ozone and biomass burning, Science, 291, 2128-2132, 2001.

Wang, C. J. L., Blake, D. R., and Rowland, F. S.: SeasonalVariations in the Atmospheric Distribution of a Reactive Chlorine Compound, Tetrachloroethene $\left(\mathrm{CCl}_{2}=\mathrm{CCl}_{2}\right)$, Geophys. Res. Lett., 22, 1097-1100, 1995.

Warneke, C., and de Gouw, J. A.: Organic trace gas composition of the marine boundary layer over the northwest Indian Ocean in April 2000, Atmos. Environ., 35, 5923-5933, 2001.

Weigelt, A., Hermann, M., van Velthoven, P. F. J., Brenninkmeijer, C. A. M., Schlaf, G., Zahn, A., and Wiedensohler, A.: Influence of clouds on aerosol particle number concentrations in the upper troposphere, J. Geophys. Res.-Atmos., 114, D01204, doi:10.1029/2008jd009805, 2009.

Woo, J. H., Streets, D. G., Carmichael, G. R., Tang, Y. H., Yoo, B., Lee, W. C., Thongboonchoo, N., Pinnock, S., Kurata, G., Uno, I., Fu, Q. Y., Vay, S., Sachse, G. W., Blake, D. R., Fried, A., and Thornton, D. C.: Contribution of biomass and biofuel emissions to trace gas distributions in Asia during the TRACE-P experiment, J. Geophys. Res.-Atmos., 108, 8812, doi:10.1029/2002jd003200, 2003. 